\title{
Patient engagement: an investigation at a primary care clinic
}

This article was published in the following Dove Press journal:

International Journal of General Medicine

I March 2013

Number of times this article has been viewed

\section{Preetinder Singh Gill}

College of Technology, Eastern Michigan University, Ypsilanti, MI, USA
Background: Engaged employees are an asset to any organization. They are instrumental in ensuring good commercial outcomes through continuous innovation and incremental improvement. A health care facility is similar to a regular work setting in many ways. A health care provider and a patient have roles akin to a team leader and a team member/stakeholder, respectively. Hence it can be argued that the concept of employee engagement can be applied to patients in health care settings in order to improve health outcomes.

Methods: Patient engagement data were collected using a survey instrument from a primary care clinic in the northern Indian state of Punjab. Canonical correlation equations were formulated to identify combinations which were strongly related to each other. In addition, the cause-effect relationship between patient engagement and patient-perceived health outcomes was described using structural equation modeling.

Results: Canonical correlation analysis showed that the first set of canonical variables had a fairly strong relationship, ie, a magnitude $>0.80$ at the $95 \%$ confidence interval, for five dimensions of patient engagement. Structural equation modeling analysis yielded a $\beta \geq 0.10$ and a Student's $t$ statistic $\geq 2.96$ for these five dimensions. The threshold Student's $t$ statistic was 1.99 . Hence it was found the $\beta$ values were significant at the $95 \%$ confidence interval for all census regions.

Conclusion: A scaled reliable survey instrument was developed to measured patient engagement. Better patient engagement is associated with better patient-perceived health outcomes. This study provides preliminary evidence that patient engagement has a causal relationship with patient-perceived health outcomes.

Keywords: patient engagement, health outcomes, communication, provider effectiveness, patient incentive

\section{Introduction}

This paper begins by exploring the existing literature to illustrate the concept of employee engagement. In the following section, a number of subconstructs of employee engagement are categorized as five key dimensions. These five dimensions of employee engagement are used to postulate five dimensions of patient engagement. Research hypotheses and research questions are presented. The next section describes the development of a survey instrument based on the five dimensions of patient engagement. This is followed by a section addressing data collection from a primary care clinic in the northern Indian state of Punjab. The data collected are then analyzed by using the canonical correlation and structural equation modeling techniques to test the hypotheses. The next section discusses the conclusions based on the results of the data analysis.
Correspondence: Preetinder S Gill College of Technology, Eastern Michigan University, I59 Sill Hall Ypsilanti, MI 48197, USA

Tel +l 7344872338

Fax +l 7344870843

Email pgill I@emich.edu 
Lastly, suggestions for future research are presented to validate and generalize the conclusions of this study.

\section{Employee engagement}

Engaged employees make organizations successful. Employees today are more aware, more educated, and more connected than ever before. ${ }^{1}$ These employees not only strive for continuous improvement, but also innovate relentlessly. Highly engaged employees improve organizational performance and stakeholder value. ${ }^{2}$ An engaged workforce ensures organizational viability by producing better business outcomes.

Researchers have not reached a consensus on the definition of employee engagement. ${ }^{3}$ However, a review of the existing research could help synthesize a fairly adequate description of the concept. Kahn maintains that employee engagement is concerned with adherence by employees to their assigned and expected roles. ${ }^{4}$ In other words, engaged employees productively apply themselves physically, cognitively, and emotionally during performance of their roles. Kahn also hypothesizes that attention and absorption are two critical components of employee engagement. Attention refers to cognitive availability and the amount of time one spends thinking about a role, while absorption means being engrossed in a role and refers to the intensity of one's focus on the role. ${ }^{5}$ Gibbons described employee engagement in terms of the emotional connection of an employee with the organization that influences him or her to apply discretionary effort to his or her work. ${ }^{6}$

\section{Dimensions of employee engagement}

Heintzman and Marson maintain that employee engagement is composed of two distinct yet related components, ie, employee commitment and employee satisfaction. ${ }^{7}$ This in fact is very similar to the seminal theory of hygiene and motivation factors proposed by Herzberg et al. ${ }^{8}$ Employee engagement could also be associated with the level of commitment or happiness a person assigns to work. ${ }^{9}$ Furthermore, engagement is the energy or passion that employees harbor for their jobs and their employer, which result in emotional and intellectual commitment to their organization. ${ }^{10}$ Nink and Klaus ${ }^{11}$ classifies the widely used Q12 ${ }^{\circledR}$ developed by Buckingham and Coffman ${ }^{12}$ as basic needs, management support, teamwork, and growth. Cummins and Worley argue that four key elements of employee engagement are power, information, knowledge/skills, and rewards. ${ }^{13}$ Robinson et al have proposed that employee engagement consists of job satisfaction, friendliness at work, cooperation, health and safety, pay and benefits, equal opportunities and fair treatment, communication, performance and appraisal, role of immediate management, and training, development, and career. ${ }^{14}$ Despite the many different ways in which employee engagement has been defined, Shaw maintains that it can be described by a few key dimensions. ${ }^{15}$ Grounded in a literature review, Gill proposes and has statistically validated five dimensions of employee engagement, ie, alignment with the organization, management effectiveness, salary and compensation, communication, and opportunity for development and recognition. ${ }^{16}$

\section{Application of employee engagement dimensions in health care}

An analogy could be made between a health care facility and a regular office setting. A patient guided by a health care provider is akin to an employee guided by a manager. On the one hand, a department of employees and managers strives to achieve better business outcomes. On the other hand, a clinic of patients and health care providers strive to achieve better health outcomes. Further, like all organizations, health care facilities are guided by policies and procedures. There could be many ways in which a health care facility might be different for other organizations, but there does seem to be a fair bit of similarity. Hence, in a health care setting, employee engagement and its five dimensions could be translated into patient engagement and its five dimensions. Proposed dimensions of patient engagement are compared with established dimensions of employee engagement in Table 1.

\section{Alignment of objectives}

Successful implementation of initiatives requires alignment of the employee with the mission/vision of the organization. ${ }^{17}$ Alignment ensures that employees comprehend clearly what they can contribute to the organization. ${ }^{18}$ Thus, proper alignment ensures better business outcomes. Similarly, in a health care setting, it is important that the objectives of patients and their health care providers are in alignment. Ideally, a health care plan and its objectives should be developed by

Table I Employee engagement versus patient engagement

\begin{tabular}{ll}
\hline Employee engagement & Patient engagement \\
\hline Alignment with organization & Alignment of objectives \\
Communication & $\begin{array}{l}\text { Communication } \\
\text { Information and encourgement } \\
\text { Opportunity for development } \\
\text { and recognition }\end{array}$ \\
$\begin{array}{l}\text { Salary and compensation } \\
\text { Management effectiveness }\end{array}$ & Patient incentives \\
\hline
\end{tabular}


consensus between the health care provider and the patient. This would not only enhance the patient's understanding but would also ensure alignment of the patient with the direction of the health care provider. Existing studies have underscored the need to involve patients in decision-making related to health care. ${ }^{19,20}$

\section{Communication}

Clear communication between health care providers and patients could clarify instructions for care effectively and could help to reduce errors and waste. Gill et al suggested that better communication could improve health literacy, which has an influence on the health status of the individual. ${ }^{21}$ Improved communication between health care providers and patients can assist in improving health outcomes. ${ }^{22-25}$ Further, interactions between patients and their caregivers could be beneficial. Gill and Whisnant reported that better communication with patients could also assist in addressing various health conditions. ${ }^{26}$

\section{Information and encouragement}

Adequate training and recognition help to foster engagement in the work force. ${ }^{27-29}$ In the health care setting, this could be translated as: information, eg, pamphlets and booklets addressing specific issues and topics, access to counselors/ social workers, and online knowledge bases and forums; and encouragement, ie, positive reinforcement, encouragement and praise for proactive initiatives and directions which are followed well. ${ }^{30}$ The importance of health literacy has been well documented. ${ }^{31,32}$

\section{Provider effectiveness}

The effectiveness of management can make or break an organization. Similarly, the effectiveness of health care providers is crucial for optimal health outcomes. ${ }^{33-35}$ Health care providers assess the patient's health status, establish a treatment plan, motivate patients, and improve their knowledge and understanding of their health condition.

\section{Patient incentive}

Like employees, patients have to take specific measures to reach predetermined (health) goals. Salary/compensation is a very effective motivator. Employees expect their organization to pay them fairly regardless of the industrial sector. ${ }^{36,37}$ In the health care setting, patients do not receive any financial compensation. However, intangible incentives could be provided in order to keep them engaged. The employee engagement dimension of salary/compensation can be translated to patient engagement in terms of: improving access and affordability; value-added services, such as providing counseling on hygiene and lifestyle; and resources needed for care, eg, creation of an interpatient medical supplies exchange system.

\section{Problem statement/research questions}

Numerous articles are available which highlight the importance of patient engagement. ${ }^{38-42}$ However, few quantitative studies have been performed in developing nations. Further, patient engagement has not been studied adequately in primary care clinics, especially in northern India. The following research questions were addressed by this study:

- What relationship, if any, exists between the patient engagement dimension of alignment of objective, as defined by the patient survey, and patient-perceived health outcomes, as defined by the patient survey, at the primary care clinic?

- What relationship, if any, exists between the patient engagement dimension of communication, as defined by the patient survey, and patient-perceived health outcomes, as defined by the patient survey, at the primary care clinic?

- What relationship, if any, exists between the patient engagement dimension of information and encouragement, as defined by the patient survey, and patient-perceived health outcomes, as defined by the patient survey, at the primary care clinic?

- What relationship, if any, exists between the patient engagement dimension of patient incentive, as defined by the patient survey, and patient-perceived health outcomes, as defined by the patient survey, at the primary care clinic?

- What relationship, if any, exists between the patient engagement dimension of provider effectiveness, as defined by the patient survey, and patient-perceived health outcomes, as defined by the patient survey, at the primary care clinic?

\section{Materials and methods Data collection}

This section describes various aspects of the development of the survey, including population, sample, internal and construct validity, readability, and scale reliability. It describes the data collection process used in this study. Statistical analyses and tests were performed at a 0.05 significance level. 


\section{External and internal validity}

The sample population used in this study included patients from a privately owned primary care clinic in the northern Indian state of Punjab. Between October 1, 2012 and December 21, 2012, 94 surveys were completed. A total of 158 patients came for follow-up visits. The response rate was $59.49 \%$. Cronbach's $\alpha$ was $84.92 \%$, demonstrating that the survey instrument had an acceptable level of scale reliability.

\section{Construct validity}

The survey instrument was developed to capture information about each of the five dimensions of patient engagement. The questions were fashioned similar to those contained in Gallup Inc's CE11(C) survey instrument, ${ }^{43}$ which has been used successfully by a number of US health organizations. ${ }^{44} 46$ The Picker Institute's dimensions of patient-centered care ${ }^{47,48}$ and survey questionnaires ${ }^{49-51}$ were also reviewed to formulate questions included in the survey instrument. Hence, it was concluded that the survey instrument had adequate construct validity.

Data were collected using a survey instrument developed using the five dimensions of patient engagement described in the previous sections. The survey instrument itself was divided into six sections. The first section, with three questions, was allocated to patient-perceived health outcomes. The following five sections were dedicated to each of the five dimensions of patient engagement. The survey instrument also contained some information concerning purpose, instructions, anonymity, and submission. A large section of the population in the state of Punjab can understand English, but most can only read and write either Hindi or Punjabi. ${ }^{52,53}$
The survey instrument was first drafted in English and then translated by the author into Hindi and Punjabi. Of note, the author is proficient in all three languages. Three versions of the survey were made available to the respondents so that they could choose the version they were comfortable with.

According to the Sarva Shiksha Abhiyan Authority of the Government of Punjab, about $81 \%$ of the population in the state have at least elementary level (fifth grade) education. ${ }^{54}$ The readability of the Hindi and Punjabi versions of the survey was assessed to be satisfactory by 12 language teachers at five accredited elementary schools in the state of Punjab. The names and locations of the teachers and the schools are confidential because permission to disclose this information was not explicitly provided by the school administrators. The English version of the survey had a Flesch Reading Ease score of 60.1 (on a scale of 0-100, where 100 is the easiest to read) and a Flesch-Kincaid grade level score of 7.3. These scores indicate that the English version of the survey is relatively easy to read. The English version of the survey is presented in Appendix A. The Hindi version of the survey is presented in Appendix B. The Punjabi version of the survey is presented in Appendix C.

Data were collected from the primary care clinic in Punjab. In order to ensure complete confidentiality and anonymity, no identifying information about the clinic, its staff, or its patients is included in this study. Patients visited the clinic because of a wide range of ailments, making it hard to measure and compare health outcomes objectively. To address this problem, patients' perception of their health outcomes was measured. Paper-based survey forms were presented to the patients upon check-in at their second visit to the primary care clinic. This was done to ensure that patients

Table 2 Survey questions and associated codes

\begin{tabular}{|c|c|c|}
\hline Question & Dimension & Code \\
\hline My opinions always seem to count in treatment plan. & Alignment of objectives & All \\
\hline My physician or an associate at this clinic cares for me as a person. & Alignment of objectives & $\mathrm{A} / 2$ \\
\hline I always understand my physician and her/his directions. & Communication & Coml \\
\hline I am always able to express my concerns at this clinic. & Communication & Com2 \\
\hline My physician always understands me. & Communication & Com3 \\
\hline My physician or an associate at this clinic always encourage me to make good lifestyle choices. & Information and encouragement & DRI \\
\hline My physician or an associate at this clinic always recognize my efforts to ensure my wellbeing. & Information and encouragement & DR2 \\
\hline I have been provided adequate information about my condition by this clinic. & Information and encouragement & DR3 \\
\hline After treatment from this clinic I am satisfied with my health outcomes. & Patient health outcome & CLI \\
\hline I will continue at this clinic. & Patient health outcome & CL2 \\
\hline I am satisfied with the services at this clinic. & Patient health outcome & CL3 \\
\hline I have the resources I need to ensure my wellbeing. & Patient incentive & Compl \\
\hline The services at this clinic are affordable. & Patient incentive & Comp2 \\
\hline This clinic is the perfect practice for people like me. & Provider effectiveness & PEffl \\
\hline My physician or an associate at this clinic always delivers on what they promise. & Provider effectiveness & PEff2 \\
\hline I can always trust the name of this clinic. & Provider effectiveness & PEff3 \\
\hline
\end{tabular}


had enough time to assess their health status since the time of their first visit. The survey forms were filled in by the patients or their accompanying friends/family members before they saw a health care provider. Participation in the survey was completely voluntary and anonymous. The patients and their accompanying friends/family members were informed that the data collected would be used for research purposes only. Furthermore, they were informed that no identifying information was being collected. The survey responses were tabulated into an electronic spreadsheet by an associate at the primary care clinic and emailed to the author for data analysis. The survey questions were coded for ease of data analysis. These codes are presented in Table 2.

\section{Results and discussion \\ Data analysis}

A descriptive data analysis for each of the survey questions is shown in Table 3. It was found that the average score for most questions was between 3 and 4. Most values for standardized skewness and standardized kurtosis are within the range of -2 and +2 . In cases where these values were outside this range, large deviations were not observed. Hence, the data were assumed to be normally distributed.

\section{Canonical correlation}

The canonical correlation technique quantifies the relationship between two sets of variables. Scalar linear combinations of the first and second set of variables are defined. The relationship between the sets of variables is quantified in terms of the magnitude of the correlation between the two scalars. ${ }^{55}$ For the purposes of this study, the survey questions associated with patient-perceived health outcomes formed the first set of variables. The survey questions associated with each of the patient engagement dimensions formed the second set of variables. The results of the canonical correlation are shown in Table 4.

It was found that every dimension of patient engagement demonstrated a fairly strong relationship with patient-perceived health outcomes at the $95 \%$ confidence interval. First combination between alignment of objectives and patient-perceived health outcomes had a canonical correlation of 0.89 and a $P$ value of $<0.01$. First combination between communication and patient-perceived health outcomes had a canonical correlation of 0.96 and a $P$ value of $<0.01$. First combination between information and encouragement and patient-perceived health outcomes had a canonical correlation of 0.88 and a $P$ value of $<0.01$. First combination between patient incentive patient-perceived health outcomes had a canonical correlation

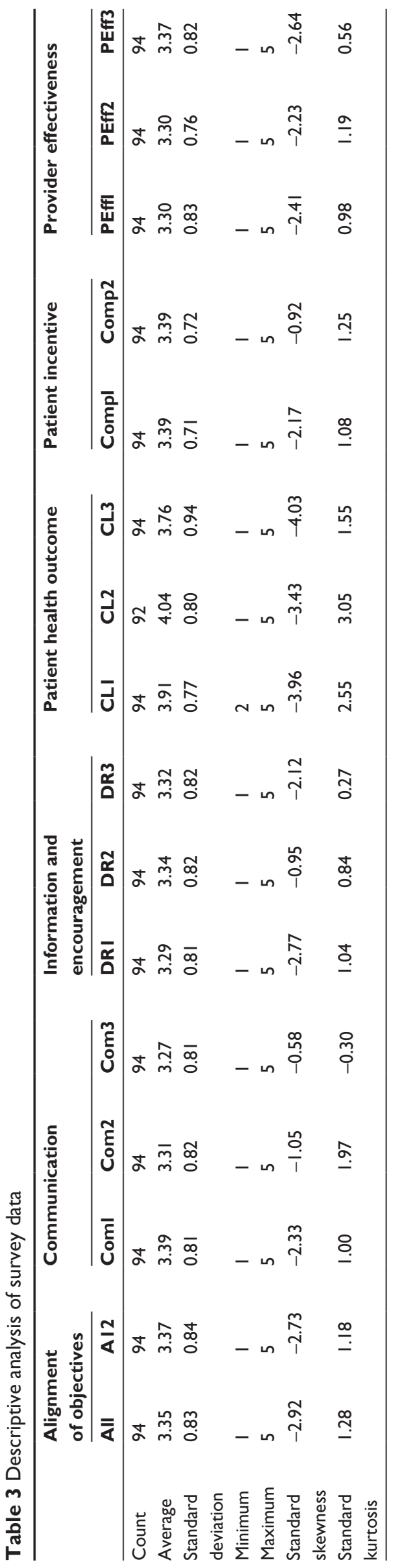


Table 4 Canonical correlation analysis by dimensions of patient engagement

\begin{tabular}{|c|c|c|c|c|}
\hline $\begin{array}{l}\text { Canonical correlation } \\
\text { of patient health outcome with }\end{array}$ & Combination \# & $\begin{array}{l}\text { Canonical } \\
\text { Correlation }\end{array}$ & $\begin{array}{l}\text { Wilks } \\
\text { Lambda }\end{array}$ & $P$-value \\
\hline Alignment of objectives & 1 & 0.89 & 0.13 & $<0.01$ \\
\hline Alignment of objectives & 2 & 0.13 & 0.98 & 0.46 \\
\hline Communication & I & 0.96 & 0.08 & $<0.01$ \\
\hline Communication & 2 & 0.13 & 0.98 & 0.76 \\
\hline Information and encouragement & 1 & 0.88 & 0.10 & $<0.01$ \\
\hline Information and encouragement & 2 & 0.24 & 0.94 & 0.27 \\
\hline Patient incentive & 1 & 0.81 & 0.26 & $<0.01$ \\
\hline Patient incentive & 2 & 0.18 & 0.97 & 0.23 \\
\hline Provider effectiveness & I & 0.95 & 0.09 & $<0.01$ \\
\hline Provider effectiveness & 2 & 0.19 & 0.94 & 0.27 \\
\hline
\end{tabular}

of 0.81 and a $P$ value of $<0.01$. First combination between provider effectiveness and patient-perceived health outcomes had a canonical correlation of 0.95 and a $P$ value of $<0.01$. The first combination equations for dimension are shown in Table 5. Canonical correlation analyses provided evidence for a strong relationship between patient-perceived health outcomes and dimensions of patient engagement. Even though all coefficients on the canonical correlation equations for dimensions of patient engagement are positive, they do not provide a clear picture of the proportionality of this relationship. The structural equation modeling technique was used to explore the proportionality issue further.

\section{Structural equation modeling}

Structural equation modeling was used to investigate the relationship between patient-perceived health outcomes and patient engagement in more depth. Structural equation modeling can be used to test causal relationships between constructs built upon measurable variables. ${ }^{56}$ The structural equation modeling technique used for this study involved

Table 5 First combination of canonical correlation equations between patient-perceived health outcome and all dimensions of patient engagement

\begin{tabular}{ll}
\hline Combination between & $\begin{array}{l}\text { First combination of canonical } \\
\text { correlation equations }\end{array}$ \\
\hline Patient health outcome & $0.64 \times \mathrm{CLI}-0.07 \times \mathrm{CL} 2+0.62 \times \mathrm{CL} 3$ \\
Alignment of objectives & $0.53 \times \mathrm{All}+0.54 \times \mathrm{AI} 2$ \\
Patient health outcome & $0.55 \times \mathrm{CLI}+0.10 \times \mathrm{CL} 2+0.63 \times \mathrm{CL} 3$ \\
Communication & $0.26 \times \mathrm{Coml}+0.43 \times \mathrm{Com} 2+0.43 \times \mathrm{Com} 3$ \\
Patient health outcome & $0.50 \times \mathrm{CLI}-0.0 \mathrm{I} \times \mathrm{CL} 2+0.73 \times \mathrm{CL} 3$ \\
Information and & $0.37 \times \mathrm{DRI}+0.37 \times \mathrm{DR} 2+0.36 \times \mathrm{DR} 3$ \\
encouragement & \\
Patient health outcome & $0.44 \times \mathrm{CLI}+0.4 \mathrm{I} \times \mathrm{CL} 2+0.5 \mathrm{I} \times \mathrm{CL} 3$ \\
Patient incentive & $0.54 \times \mathrm{Compl}+0.54 \times \mathrm{Comp} 2$ \\
Patient health outcome & $0.56 \times \mathrm{CLI}+0.03 \times \mathrm{CL} 2+0.66 \times \mathrm{CL} 3$ \\
Provider effectiveness & $0.38 \times \mathrm{PEffl}+0.37 \times \mathrm{PEff} 2+0.36 \times \mathrm{PEff} 3$ \\
\hline
\end{tabular}

the covariance-based partial least square path model method. The path model is an a priori hypothesis about a pattern of linear relationships among a set of observed and unobserved variables. It is defined by two sets of linear equations, ie, the inner model and the outer model. The inner model specifies the relationships between unobserved or latent variables. The outer model specifies the relationships between a latent variable and its observed or manifest variables. Latent variables are hypothetical constructs that cannot be directly measured, and are represented by multiple manifest variables that serve as representatives of the underlying constructs. ${ }^{57-59}$ The structural equation modeling-partial least square path model can be used for any type of distribution and any size of sample. ${ }^{58}$

The individual path coefficients of the structural equation modeling-partial least square path model can be interpreted as standardized $\beta$ coefficients of ordinary least squares regressions. Structural paths, the signs of which are in keeping with a priori postulated algebraic signs, provide a partial

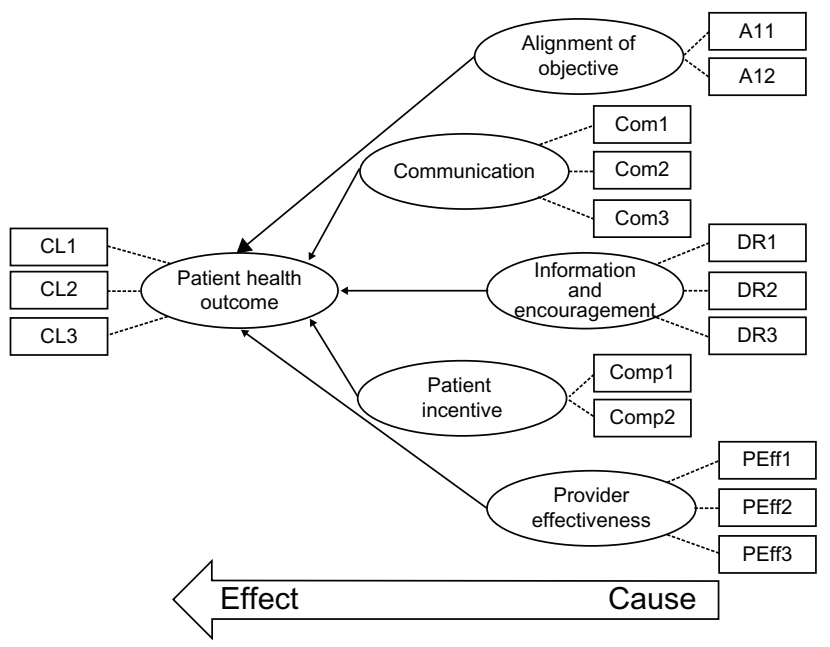

Figure I Structural equation modeling-partial least squares path model for all paths between patient-perceived health outcomes and dimensions of patient engagement. 


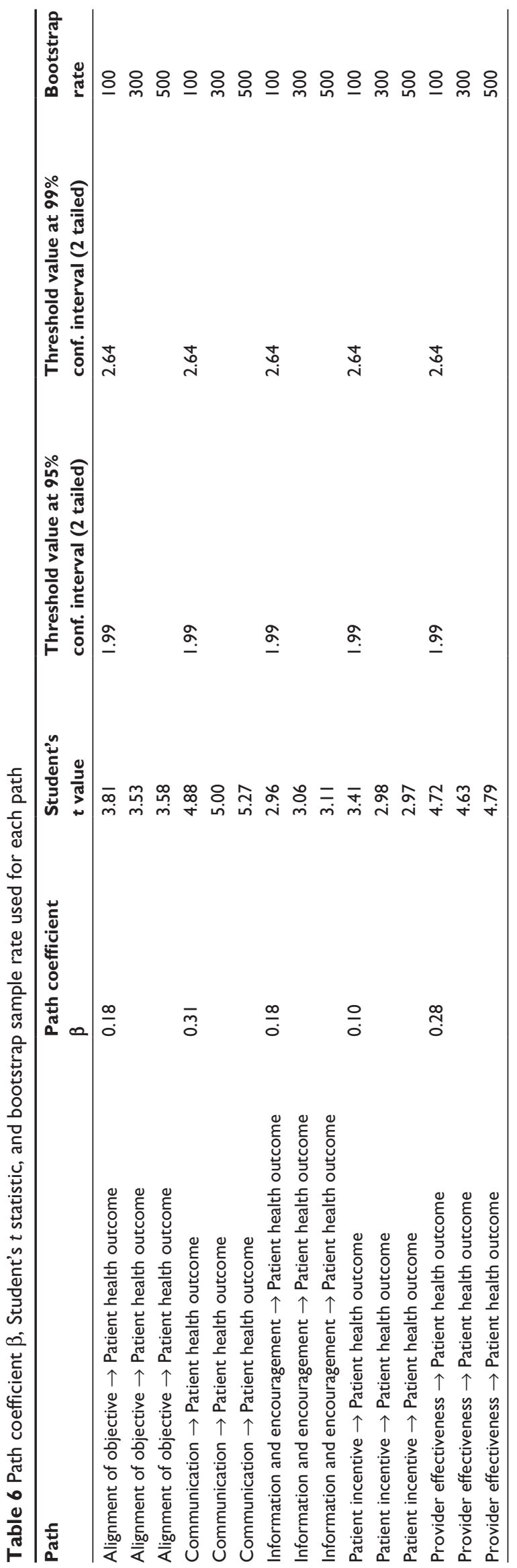

empirical validation of the theoretically assumed relationships between latent variables. Paths that possess an algebraic sign contrary to expectations do not support the hypotheses formed a priori. Parameter estimates are obtained based on the ability to minimize the residual variance of dependent variables. ${ }^{57} \mathrm{~A}$ bootstrapping resampling algorithm was used to determine the confidence intervals in terms of the Student's $t$ statistic for the $\beta$ coefficients. This in turn helps to draw statistical inferences. ${ }^{57}$

The structural equation modeling-partial least square path model and $\beta$ coefficients are shown in Figure 1. The Student's $t$ values and bootstrap sample rates are shown in Table 6. For data samples with 92 degrees of freedom, statistical significance is demonstrated at a two-sided $95 \%$ confidence interval if the Student's $t$ values are $\geq 1.99$. At a $99 \%$ confidence interval, statistical significance is demonstrated by Student's $t$ values $\geq 2.64$. The degrees of freedom associated with the threshold values were calculated from the number of data points. For all dimensions of patient engagement, the Student's $t$ statistic was found to be greater than the threshold values for both $95 \%$ and $99 \%$ confidence intervals. Furthermore, all the $\beta$ values are positive. These findings provide preliminary evidence that a high level of patient engagement could result in better health outcomes.

The results of canonical correlation and structural equation modeling analyses not only provided statistical evidence but also quantified the relationships between dimensions of patient engagement, as defined by the patient survey, and patient-perceived health outcomes, as defined by the patient survey at the primary care clinic.

\section{Conclusion}

This data analysis shows that five dimensions of patient engagement, ie, alignment of objective, communication, information and encouragement, patient incentive, and provider effectiveness had a statistically significant relationship with patient-perceived health outcomes at a primary care clinic. It must be noted that the results of this study come from a single primary care unit in a specific region. Hence it is necessary for this exercise be repeated in future research at other clinics and locations in order to generalize and validate these findings. Canonical correlation and structural equation modeling showed that, among the dimensions of patient engagement, patient incentive had the least impact on patient-perceived health outcomes. On the other hand, communication and provider effectiveness had the most impact. This finding provides a clue as to where health care facilities should invest to maximize their returns. In other words, if 
health care facilities could improve the soft skills of their health care providers, health outcomes could be improved for patients. Canonical equations could serve as predictive models to calculate projected change in the patient-perceived health outcomes given a specific change in patient engagement. Nonetheless, it must be underscored that the results of this study are limited to only one health clinic, and need to be validated by repeating similar studies in different clinics and over extended time periods.

The survey instrument showed high scale reliability (Cronbach's $\alpha=85 \%$ ). The readability (Flesch Reading Ease score $=60.1$, Flesch-Kincaid grade level score $=7.3$ ) of the English version of the survey could be rated as fairly easy. In addition, the subjective readability of the Hindi and Punjabi versions was also rated as acceptable. Hence, the survey instrument could be used in health care settings in other geographical regions.

The results of this structural equation modeling analysis provide preliminary evidence that patient engagement has a causal impact on patient-perceived health outcomes. These findings consolidate the conclusions of numerous previous studies. ${ }^{60-65}$ Future experimental research is needed to verify the effect of patient engagement on specific objectively measured patient health outcomes. Such studies could also isolate specific dimensions of patient engagement which consistently have the most impact on patient health outcomes. Generalization of the causal relationship could help health care facilities to invest their limited resources effectively to maximize the health benefits for their patients.

\section{Disclosure}

The author reports no conflicts of interest in this work.

\section{References}

1. Dennis P. Lean Production Simplified: A Plain Language Guide to the World's most Powerful Production System, 2nd ed. New York, NY: Productivity Press; 2007.

2. Lockwood NR. Leveraging employee engagement for competitive advantage: HR's strategic role. HRMagazine. 2007;52:S1.

3. Gatenby M, Rees C, Soane E, Truss C. Employee engagement in context. Chartered Institute of Personnel and Development, 2006. Available from: http://www.cipd.co.uk/NR/rdonlyres/6D7D52C8-6E51-4539A189-1E2D6EBEF01F/0/employee_engagement_context.pdf. Accessed December 25, 2012.

4. Kahn WA. Psychological conditions of personal engagement and disengagement at work. Acad Manage J. 1990;33:692-724.

5. Rothbard NP. Enriching or depleting? The dynamics of engagement in work and family roles. Adm Sci Q. 2001;46:655-684.

6. Gibbons J. Employee engagement a review of current research and its implications. The Conference Board of Canada, November, 2006. Available from: http://www.conferenceboard.ca/e-library/abstract. aspx?did=1831. Accessed December 25, 2012.

7. Heintzman R, Marson, B. People, service and trust: is there a public sector service value chain? Int Rev Adm Sci. 2005;71:549-575.
8. Herzberg F, Mausner B, Snyderman BB. The Motivation to Work. New York, NY: Wiley; 1959.

9. Peters M. Employee engagement: A research snapshot. Cross Government Research Policy and Practice Branch, Office of the Chief Information Officer, Ministry of Labour and Citizens' Services, Government of British Columbia, Canada, November 23, 2007. Available from: http://www.cio.gov.bc.ca/local/cio/kis/pdfs/employee_engagement. pdf. Accessed December 25, 2012.

10. Baumruk R. The missing link: the role of employee engagement in business success. Workspan. 2004;47:48-52.

11. Nink M, Klaus W. Involving employee in change. Personalwirtschaft. German. September, 2011. Available from: http://archiv.personalwirtschaft.de/wkd_pw/cms/website.php?id=/de/jahrgang/2011/09/ personalwirtschaft. Accessed December 25, 2012.

12. Buckingham M, Coffman C. First, Break all the Rules: What the World's Greatest Managers do Differently. New York, NY: Simon and Schuster; 1999.

13. Cummings TG, Worley CG. Organization Development and Change. Mason, OH: Thomson/South-Western; 2005.

14. Robinson D, Perryman S, Hayday S. The Drivers of Employee Engagement. Brighton, UK: Institute for Employment Studies; 2004.

15. Shaw K. An engagement strategy process for communicators. Strategic Communication Management. 2005;9:26-29.

16. Gill PS. An investigation of employee engagement and business outcomes at an engineering services firm. PhD Dissertation. Ypsilanti, MI: College of Technology Eastern Michigan University; 2012.

17. Gagnon MA, Michael JH. Employee strategic alignment at a wood manufacturer: an exploratory analysis using lean manufacturing. Forest Products Journal. 2003;53:24-29.

18. Loch $\mathrm{CH}$. Mobilizing an $\mathrm{RD}$ organization through strategy cascading. Research-Technology Management. 2008;51:18-26.

19. Edwards A, Elwyn G. Inside the black box of shared decision making: distinguishing between the process of involvement and who makes the decision. Health Expect. 2006;9:307-320.

20. Saba GW, Wong ST, Schillinger D, et al. Shared decision making and the experience of partnership in primary care. Ann Fam Med. 2006;4:54-62.

21. Gill PS, Gill TS, Kamath A, Whisnant B. Readability assessment of concussion and traumatic brain injury publications by Centers for Disease Control and Prevention. Int J Gen Med. 2012;5: 923-933.

22. Schillinger D, Piette J, Grumbach K, et al. Closing the loop: Physician communication with diabetic patients who have low health literacy. Arch Intern Med. 2003;163:83-90.

23. Detmar SB, Muller MJ, Schornagel JH, Wever LD, Aaronson NK. Health-related quality-of-life assessments and patient-physician communication: a randomized controlled trial. JAMA. 2002;288: 3027-3034.

24. Cousin G, Schmid Mast M, Roter DL, Hall JA. Concordance between physician communication style and patient attitudes predicts patient satisfaction. Patient Educ Couns. 2012;87:193-197.

25. Rudd RE, Rosenfeld L, Simonds VW. Health literacy: a new area of research with links to communication. Atl J Commun. 2012;20: $16-30$.

26. Gill PS, Whisnant B. A qualitative assessment of an online support community for ovarian cancer patients. Patient Relat Outcome Meas. 2012;3:51-58.

27. Kinsey C. Using rewards and benefits to motivate and engage. Strategic HR Review. 2009;8:47-48.

28. Axtell CM, Holman DJ, Unsworth KL, Wall TD. Shopfloor innovation: facilitating the suggestion and implementation of ideas. JOccup Organ Psychol. 2000;73:265-285.

29. Sand T, Cangemi J, Ingram J. Say again? What do associates really want at work? Organization Development Journal. 2011;29:101.

30. Gill PS. Improving Health Outcomes: Applying Dimensions of Employee Engagement to Patients. The International Journal of Health, Wellness and Society. U S A. In press 2013. 
31. Roter DL, Stashefsky-Margalit R, Rudd R. Current perspectives on patient education in the US. Patient Educ Couns. 2001;44:79-86.

32. Nutbeam D. Health literacy as a public health goal: a challenge for contemporary health education and communication strategies into the 21st century. Health Promot Int. 2012;15:259-267.

33. Saxe JS. Promoting healthy lifestyles and decreasing childhood obesity: increasing physician effectiveness through advocacy. Ann Fam Med. 2011;9:546-548.

34. Marcell AV, Halpern-Felsher BL. Adolescents' health beliefs are critical in their intentions to seek physician care. Prev Med. 2005;41:118-125.

35. Cutrona SL, Choudhry NK, Stedman M, et al. Physician effectiveness in interventions to improve cardiovascular medication adherence: a systematic review. J Gen Intern Med. 2010;25:1090-1096.

36. Gordon PJ. Customer satisfaction $=$ employee compensation. Circuits Assembly. 1999;10:34.

37. O'Connell $\mathrm{K}$. The importance of strategically designed compensation plans. Benefits and Compensation Digest. 2007;44:20.

38. Morgan A. Patient engagement. Cancer Nursing Practice. 2011;10:9.

39. Coulter A. Patient engagement - what works? J Ambul Care Manage. 2012;35:80-89.

40. Weinstock M. Improving patient engagement. Hosp Health Netw. 2012;86:32-33.

41. Clancy CM. Patient engagement in health care. Health Serv Res. 2011;46:389-393.

42. Cantlupe J. Physicians and patient engagement. The Doctor's Office. 2012;31:5.

43. Applebaum A. The constant customer. Gallup Management Journal. 2001;17:1-5

44. Take Care Health Systems LLC. Gallup Patient Engagement Scores Quality and Patient Satisfaction Scores, August 31, 2012. Available from: http://takecarehealth.com/Gallup-PatientEngagement-Scores. aspx. Accessed December 1, 2012.

45. Strawhecker P. Lessons from high performing hospitals: Achieving patient and family centered care. Presented at the 11th Consumer Assessment of Healthcare Providers and Systems and 1st Surveys on Patient Safety Culture User Group Meeting, Scottsdale, AZ, December 3-5, 2008.

46. Ardabell TR. Toni's corner. Bon Secours St Mary's Hospital Newsletter. 2010;9:1. Available from: http://www.bsvaf.org/document. doc?id=80. Accessed May 7, 2012.

47. Picker Institute. Implementation Manual. Boston, MA: Picker Institute; 1999.

48. Epstein RM, Franks P, Fiscella K, et al. Measuring patient-centered communication in patient-physician consultations: theoretical and practical issues. Soc Sci Med. 2005;61:1516-1528.

49. Jenkinson C, Coulter A, Bruster S, Richards N, Chandola T. Patients' experiences and satisfaction with health care: results of a questionnaire study of specific aspects of care. Qual Saf Health Care. 2002;11: $335-339$.
50. Jenkinson C, Coulter A, Bruster S. The Picker Patient Experience Questionnaire: development and validation using data from inpatient surveys in five countries. Int J Qual Health Care. 2002;14: 353-358.

51. Jenkinson C, Coulter A, Gyll R, Lindström P, Avner L, Höglund E. Measuring the experiences of health care for patients with musculoskeletal disorders (MSD): development of the Picker MSD questionnaire. Scand J Caring Sci. 2002;16:329-333.

52. Pandharipande R. Minority matters: issues in minority languages in India International Journal on Multicultural Societies. 2002;4:213-234.

53. The Times of India. Indiaspeak: English is our 2nd language. The Times of India, March 14, 2010. Available from: http://articles.timesofindia. indiatimes.com/2010-03-14/india/28117934_1_second-languagespeakers-urdu. Accessed December 23, 2012.

54. Sarva Shiksha Abhiyan Authority, Punjab, India. Educational Profile. Sarva Shiksha Abhiyan, 2008. Available from: http://www.ssapunjab. org/sub\%20pages/eduprofile.htm. Accessed June 1, 2012.

55. Gatignon H. Statistical Analysis of Management Data. New York, NY: Springer Science + Business Media; 2010.

56. Anderson JC, Gerbing DW. Some methods for respecifying measurement models to obtain unidimensional construct measurement. J Market Res. 1982;19:453-460.

57. Henseler J, Ringle CM, Sinkovics RR. The use of partial least squares path modeling in international marketing. Advances in International Marketing. 2009;20:277-319.

58. Shah R, Goldstein SM. Use of structural equation modeling in operations management research: looking back and forward. Journal of Operations Management. 2006;24:148-169.

59. Green DH, Ryans AB. Entry strategies and market performance: causal modeling of a business simulation. Journal of Product Innovation Management. 1990;7:45-58.

60. Lorig KR, Sobel DS, Stewart AL, et al. Evidence suggesting that a chronic disease self-management program can improve health status while reducing hospitalization: a randomized trial. Med Care 1999;37:5-14.

61. Beach MC, Keruly J, Moore RD. Is the quality of the patient-provider relationship associated with better adherence and health outcomes for patients with HIV? J Gen Intern Med. 2006;21:661-665.

62. Roter DL, Hall JA, Merisca R, Nordstrom B, Cretin D, Svarstad B. Effectiveness of interventions to improve patient compliance: a metaanalysis. Med Care. 1998;36:1138-1161.

63. Stewart M, Brown JB, Donner A, et al. The impact of patient-centered care on outcomes. J Fam Pract. 2000;49:796-804.

64. Trummer UF, Mueller UO, Nowak P, Stidl T, Pelikan JM. Does physician-patient communication that aims at empowering patients improve clinical outcome? A case study. Patient Educ Couns. 2006;61: 299-306.

65. Stewart MA. Effective physician-patient communication and health outcomes: a review. CMAJ. 1995;152:1423-1433. 


\section{Appendix A \\ Patient engagement survey (English version)}

\section{Purpose:}

This survey is being conducted to assist this clinic in identifying patient concerns and improving its performance.

\section{Instructions:}

Please complete all of the questions in each of the following sections. In doing so, please provide only one response for each scaled item.

\section{Anonvmity:}

Please do not reveal your identity. No identifying information is being collected. No identifying information is needed to complete this survey.

\section{Submission:}

Please complete and submit this survey in the collection box by the front desk.

\section{Patient Perceived Health Outcomes}

- After treatment from this clinic I am satisfied with my health outcomes. Strongly Disagree Disagree No Opinion Agree Strongly Agree

- I will continue at this clinic.

Strongly Disagree Disagree No Opinion Agree Strongly Agree

- I am satisfied with the services at this clinic.

Strongly Disagree Disagree No Opinion Agree Strongly Agree

\section{Provider Effectiveness}

- This clinic is the perfect practice for people like me.

Strongly Disagree Disagree No Opinion Agree Strongly Agree

- My physician or an associate at this clinic always delivers on what they promise.

Strongly Disagree Disagree No Opinion Agree Strongly Agree

- I can always trust the name of this clinic.

Strongly Disagree Disagree No Opinion Agree Strongly Agree

\section{Communication}

- I always understand my physician and her/his directions.

Strongly Disagree Disagree No Opinion Agree Strongly Agree

- I am always able to express my concerns at this clinic.

Strongly Disagree Disagree No Opinion Agree Strongly Agree

- My physician always understands me.

Strongly Disagree Disagree No Opinion Agree Strongly Agree

\section{Patient incentive}

- I have the resources I need to ensure my wellbeing

Strongly Disagree Disagree No Opinion Agree Strongly Agree

- The services at this clinic are affordable.

Strongly Disagree Disagree No Opinion Agree Strongly Agree

\section{Alignment of objectives}

- My opinions always seem to count in treatment plan.

Strongly Disagree Disagree No Opinion Agree Strongly Agree

- My physician or an associate at this clinic always cares for me as a person

Strongly Disagree Disagree No Opinion Agree Strongly Agree

\section{Information \& encouragement}

- My physician or an associate at this clinic always encourage me to make good lifestyle choices.

Strongly Disagree Disagree No Opinion Agree Strongly Agree

- My physician or an associate at this clinic always recognize my efforts to ensure my wellbeing

Strongly Disagree Disagree No Opinion Agree Strongly Agree

- I have been provided adequate information about my condition by this clinic.

Strongly Disagree Disagree No Opinion Agree Strongly Agree 


\section{Appendix B}

\section{Patient engagement survey (Hindi version)}

उद्देश्य:

इस सर्वेक्षण से हम आपके मुद्दों की पहचान करना चाहते हैं ताकि हम अपने प्रदर्शन में सुधार सकें।

निर्देश:

प्रत्येक प्रश्न का उत्तर दें। हर प्रश्न का केवल एक उत्तर दें।

आपकी पहचान:

अपनी पहचान उजागर मत करें| कोई पहचान संबंधित जानकारी एकत्र नहीं की जा रही। पहचान संबंधित जानकारी इस सर्वेक्षण को पूरा करने के लिए आवश्यक नहीं है।

संग्रह:

इस सर्वेक्षण को पूरा करने के बाद इसे क्लिनिक के सामने लगे संग्रह बॉक्स में डाल दें।

\section{रोगी व्यक्त स्वास्थ्य परिणाम}

- इस क्लिनिक से उपचार के बाद मैं अपने स्वास्थ्य परिणामों से संतुष्ट हूँ।

पूरी तरह असहमत असहमत कोई राय नहीं सहमत पूरी तरह सहमत

- मैं इस क्लिनिक के साथ बना/बनी रहूँगा/रहुँगी|

पूरी तरह असहमत असहमत कोई राय नहीं सहमत पूरी तरह सहमत

- मैं इस क्लिनिक की सेवाओं से संतुष्ट हूँ।

पूरी तरह असहमत असहमत कोई राय नहीं 1 सहमत पूरी सहमत स्वास्थ्य कार्यकर्ता प्रभावशीलता

- यह क्लिनिक मेरे जैसे लोगों के लिए एकदम सही है।

पूरी तरह असहमत असहमत काई नहीं सहमत परह सहमत

- मेरा/मेरी चिकित्सक या इस क्लिनिक का/की कोई कर्मचारी हमेशा स्वयं-नियत कार्य पूर्ण करते हैं।

पूरी तरह असहमत असहमत कोई राय नहीं सहमत पूरी सहमत

- मैं हमेशा इस क्लिनिक के नाम पर भरोसा कर सकता/सकती हूँ।

पूरी तरह असहमत असहमत कोई राय नहीं कूत् सहत् सहमत संवाद

- मैं हमेशा अपने चिकित्सक और उनके निर्देशों को समझ सकता/सकती हूँ।

पूरी तरह असहमत असहमत कोई नहीं सू सूत् सहमत

- इस क्लिनिक में मैं अपनी चिंताओं को व्यक्त कर सकता/सकती हूँ।

पूरी तरह असहमत असहमत कोई राय नहीं 1 सहमत तरह सहमत

- मेरा/मेरी चिकित्सक मुझे हमेशा समझता/समझती है।

पूरी तरह असहमत असहमत कोई राय नहीं सहमत परह सहमत प्रतिफल

- मेरे पास अपना स्वास्थ्य ठीक रखने के लिय पर्याप्त संसाथन हैं।

पूरी तरह असहमत असहमत कोई राय नहीं कूत् सूरी तरह सहतत

- इस क्लिनिक की सेवाएं किफायती हैं।

पूरी तरह असहमत असहमत कोई राय नहीं कूत् सह सहमत

उद्देश्यों की सहमति

- मेरी राय हमेशा उपचार योजना में शामिल जाती की है।

पूरी तरह असहमत असहमत कोई राय नहीं कूत् सूरी तरह सहत

- मेरा/मेरी चिकित्सक या इस क्लिनिक का/की कोई कर्मचारी हमेशा मेरी परवाह करते हैं।

पूरी तरह असहमत असहमत कोई राय नहीं सहमत पूरी तरह सहमत 


\section{सूचना और प्रोत्साहन}

- मेरा/मेरी चिकित्सक या इस क्लिनिक का/की कोई कर्मचारी हमेशा मुझे अच्छी जीवन शैली अपनाने के लिए प्रोत्साहित करते हैं।

पूरी तरह असहमत असहमत कोई राय नहीं सू सरम सहमत

- मेरा/मेरी चिकित्सक या इस क्लिनिक का/की कोई कर्मचारी हमेशा मेरे स्वास्थ्य से संबंधित प्रयासों को मान्यता देते हैं।

पूरी तरह असहमत असहमत कोई राय नहीं कूरत तरह सहमत

- इस क्लिनिक द्वारा मुझे मेरे स्वास्थ्य से संबंधित पर्याप्त जानकारी उपलब्ध कराई है।

पूरी तरह असहमत

असहमत

कोई राय नहीं

सहमत

पूरी तरह सहमत 


\section{Appendix C \\ Patient engagement survey (Punjabi version)}

छ्रेटेम:

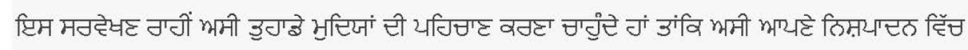
मुयान मरीप्ये|

हिगटेम :

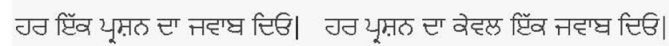

उुग'डी यगित्चः

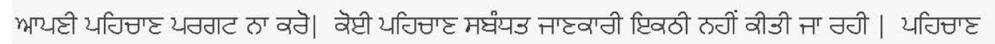

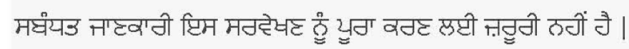

मींगिए:

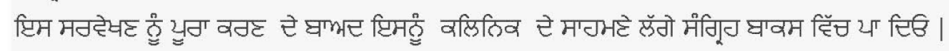

\section{ठेगी दिभवर मिग्ड रडीसे}

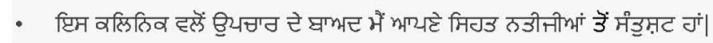

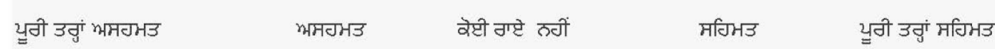

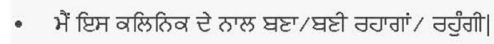

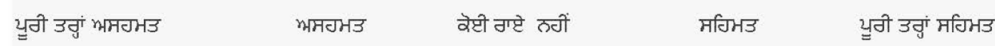

- में प्टिम वस्तिरिव टीभां मेहा्टां ऊें मंड्रमृट गं।

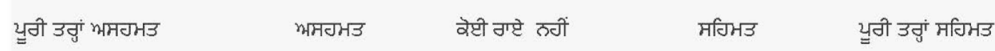

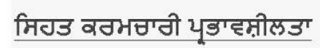

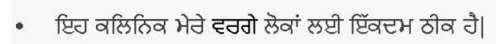

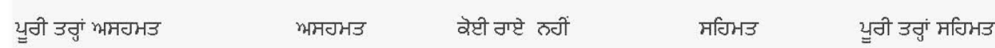

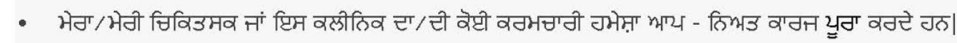

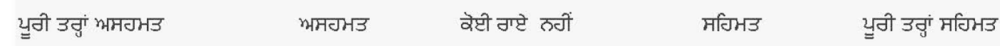

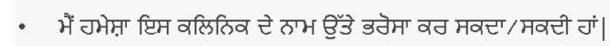

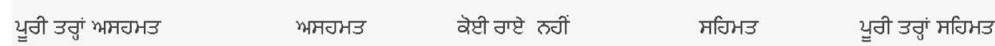
मंहार

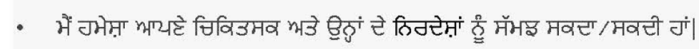

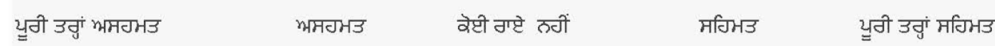

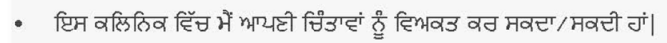

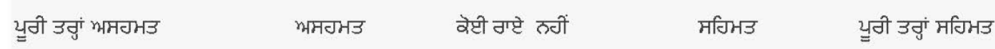

- भेठ $/$ भेठी चिविडमव भैत्रु गभेम़ा मॅभइटा/मॅभइटी चै।

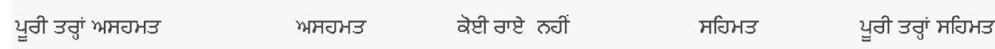
यूडीढए

- भेते वेल भथट्टी मिनड ठीव ठॅधट लप्टी वाढ़ी मंमायत गत।

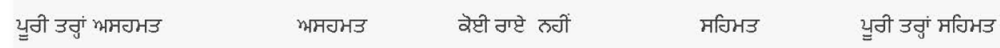

- प्रिम वस्किकिव टीभां मेटाटां विढाप्टिती गत।

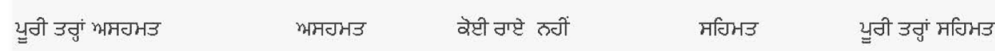




\begin{tabular}{|c|c|c|c|c|}
\hline यूती उतुं भमनभउ & भमवभउ & वेप्टी ठएप्टे हनीं & मािभि & युती उतुं \\
\hline \multicolumn{5}{|l|}{ मचिभि } \\
\hline - भेठ /भेठी चिठि & य्रम वस्रिठিव & †े रेपी वतभच्ती & थतहान व & \\
\hline यूनी उवुं भमगभउ & भमगभउ & रेपी गए्टे हवीं & मगिभЗ & युती उतुं मगिभउ \\
\hline
\end{tabular}

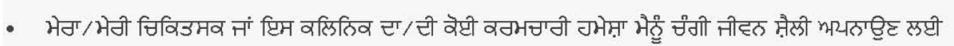

येउउमगिक वण्टे उठ।

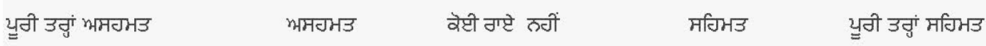

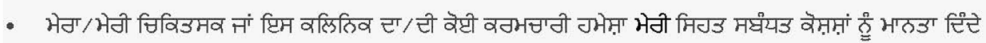

गठ।

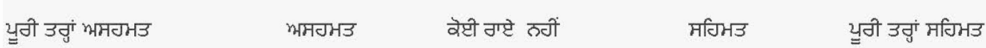

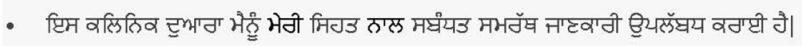

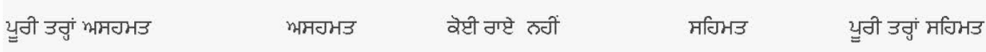

International Journal of General Medicine

Dovepress

\section{Publish your work in this journal}

The International Journal of General Medicine is an international, peer-reviewed open-access journal that focuses on general and internal medicine, pathogenesis, epidemiology, diagnosis, monitoring and treatment protocols. The journal is characterized by the rapid reporting of reviews, original research and clinical studies across all disease areas.

A key focus is the elucidation of disease processes and management protocols resulting in improved outcomes for the patient. The manuscript management system is completely online and includes a very quick and fair peer-review system. Visit http://www.dovepress.com/ testimonials.php to read real quotes from published authors.

Submit your manuscript here: http://www.dovepress.com/international-journal-of-general-medicine-journal 